\title{
Menggugat Ruang Publik Melalui Gerakan Masyarakat (Studi Kasus Gerakan Warga Berdaya di Yogyakarta)
}

\section{Oleh: Hamada Adzani Mahaswara ${ }^{1}$}

\begin{abstract}
Abstrak
Kehidupan warga di perkotaan tak terkecuali di Yogyakarta juga mengalami dinamika dan perubahan, baik itu perubahan pada aspek fisik, sosial bahkan kultural. Sebagai kota tujuan pendidikan, terdapat lebih dari limapuluh (50) perguruan tinggi di Yogyakarta. Di sisi lain sebagai tujuan wisata, Yogyakarta memiliki sejumlah destinasi yang terjangkau meskipun prasarana transportasi publik masih menjadi hambatan. Selain itu, atmosfer seni dan budaya yang dimiliki Yogyakarta menjadikannya "paket lengkap" dan semakin menarik sebagai tujuan wisata. Tak heran dalam beberapa tahun terakhir Yogyakarta semakin padat, selain itu juga tumbuh sebagai pangsa pasar yang strategis bagi para pemilik modal. Kondisi yang membuat lingkungan kehidupan masyarakat urban di Yogyakarta yang semakin berubah inilah yang memunculkan bentuk protes melalui partisipasi warga khususnya mereka yang memperjuangkan pentingnya ruang publik di Yogyakarta. Gerakan ini menamakan dirinya Warga Berdaya.
\end{abstract}

\section{Kata Kunci:}

Partisipasi warga, Ruang Publik, Warga Berdaya

\footnotetext{
Abstract

There is no exception for most residents of urban areas of Yogyakarta in experiencing the dynamics of physical, social and cultural changes. Yogyakarta is for so long has been

${ }^{1}$ Hamada Adzani Mahaswara adalah mahasiswi pada Program studi Sarjana, Departemen Sosiologi, FISIPOL UGM. Artikel ini pernah dipresentasikan pada kegiatan Fisipol Research Day pada bulan November 2015 dan saat ini sedang menyelesaikan penulisan skripsinya.
}

known as a destination for tourism and education especially with its brand as the herritage city and the city of education. There are more than fifty (50) universities in Yogyakarta. On the other hand, Yogyakarta is also known as a tourism destination which accomodation are quite affordable despite its lacking support for public transportation. In addition to the its brand as the city of education, the atmosphere of art and culture in Yogyakarta has been making the city as a "complete package" attempting to be attractive as a tourist destination. In fact, within few years Yogyakarta now has become increasingly more crowded that attracts the interests of investors to gain more benefits. However, the investments in Yogyakarta also deteriorate the environment which in turn has induced a form of protest from its citizens. They claim their struggle for the importance of public spaces in Yogyakarta. This movement calls itself 'Warga Berdaya' or the Empowered Citizens of Yogyakarta.

\section{Keywords:}

Citizen participation, Public Space, Warga Berdaya (Empowered Citizen of Yogyakarta)

\section{Pendahuluan}

Sebagai sebuah gerakan, Warga Berdaya berhadapan dengan struktur yang besar, yakni negara dan korporasi. Oleh karena itu, seiring dengan berjalannya waktu, menjadi menarik untuk melihat narasi dan konstruksi apa yang tengah dibongkar oleh Warga Berdaya. Menjelaskan bagaimana warga kota dewasa melihat serta memaknai situasi lingkungan, sosial, dan politik di Yogyakarta. Memahami dan mendeskripsikan bentuk (wujud/rupa) aktivisme Warga Berdaya sebagai sebuah gerakan masyarakat urban di Yogyakarta berdasarkan media atau sarana yang 
dimanfaatkannya. Melihat pola aktivisme yang dilakukan. Pola dalam hal ini merujuk pada sistem dan cara kerja yang dikerjakan oleh Warga Berdaya. Memetakan serta menganalisis aktor (jaringan) yang terlibat dalam aktivisme Warga Berdaya. Penting untuk mengetahui latar belakang aktor serta menganalisis keterlibatan para aktor.

Kehidupan warga di perkotaan selalu mengalami dinamika. Perubahan, baik itu perubahan dalam aspek fisik dan sosial senantiasa terjadi seiring dengan tuntutan zaman yang bergerak maju. Tidak terkecuali Yogyakarta, kota dengan sejumlah titel yang disematkan padanya. Sebagai kota tujuan pendidikan, terdapat lebih dari 50 perguruan tinggi di Yogyakarta. Di sisi lain sebagai tujuan wisata, Yogyakarta memiliki sejumlah destinasi yang terjangkau dan didukung dengan sarana transportasi yang cukup memadai. Selain itu, atmosfer seni dan budaya yang dimiliki Yogyakarta menjadikannya "paket lengkap" dan semakin menarik sebagai tujuan wisata. Biaya hidup yang relatif terjangkau membuat Yogyakarta menjadi pilihan migrasi banyak orang. Tak heran dalam beberapa tahun terakhir Yogyakarta semakin padat, selain itu juga tumbuh sebagai pangsa pasar yang strategis bagi para pemilik modal.

Ruang publik Yogyakarta menjadi persoalan yang ramai diperbincangkan dalam beberapa tahun terakhir karena perubahannya yang cepat. Ruang publik yang dianggap sebagai ruang milik warga, kini berubah fungsinya lantas menghilang dan digantikan bangunan-bangunan baru yang tidak merepresentasikan identitas Yogyakarta. Ruang publik-mengambil contoh trotoar-kini telah beralihfungsi menjadi lapak bagi pedagang kaki lima. Di daerah utara Yogyakarta, terlihat tak ada satupun trotoar yang dibiarkan kosong. Sepanjang Jalan Kaliurang, pedagang kaki lima (PKL) menyesakki trotoar hingga ruas jalan. Di sisi lain, seringkali bangunanbangunan baru yang tidak memiliki lahan luas, memanfaatkan trotoar dan ruas-ruas jalan sebagai tempat parkir. Alhasil kemacetan seringkali terjadi di jam padat karena hampir separuh badan jalan terkooptasi sebagai lahan parkir. Sementara itu, bicara mengenai trotoar sendiri, meningkatnya volume kendaraan bermotor di Yogyakarta berimbas pada berubahnya fungsi trotoar. Selain untuk lahan parkir sebagaimana yang dijelaskan sebelumnya, trotoar menjadi 'alternatif jalan baru' bagi kendaraan roda dua ketika kemacetan terjadi. Mengandalkan azas kecepatan, melaju di atas trotoar dipilih karena dapat mendahului kendaraan roda empat yang stagnan di perempatan.

Bicara tentang perubahan, dalam beberapa tahun terakhir, Yogyakarta seolah mengalami akselerasi dalam pembangunan. Ruang-ruang spasial yang sebelumnya kosong, diperebutkan oleh berbagai pihak. Pembangunan pemukiman baru, hotel, apartemen dan mall mendominasi. Pembangunan hotel, apartemen terlihat masif di Kota Yogyakarta dan Kabupaten Sleman. Kabupaten Bantul dan Kulonprogo juga menjadi sasaran pembangunan perumahan, meski frekuensinya tidak sebanyak dua kabupaten yang telah disebutkan sebelumnya.

\section{Metode Penelitian}

Adapun fokus penelitian ini akan mengambil tempat di Daerah Istimewa Yogyakarta. Kota Yogyakarta dan Kabupaten Sleman akan menjadi lokasi penelitian paling intensif mengingat di dua wilayah ini perubahan fisik dan sosial terjadi secara masif dalam rentang waktu tiga tahun terakhir. Selain itu, penulis juga akan mengamati lokasi-lokasi yang pernah menjadi tempat aksi Gerakan Warga Berdaya untuk melihat konteks yang ada. Namun demikian, penelitian ini juga tidak menutup kemungkinan untuk bergeser pada kabupaten atau wilayah lain di Yogyakarta sesuai dengan dinamika Gerakan Warga Berdaya. Mengingat pergerakannya yang senantiasa dinamis, maka penulis membatasi rentang waktu penelitian mulai daru tahun 2012 hingga tahun pertengahan tahun 2015.

Oleh karena itu untuk menurunkan konsep dan perspektif teoritis sebagaimana 
dijelaskan sebelumnya, penulis memilih menggunakan pendekatan studi kasus dalam penelitian ini. Studi kasus dipilih karena dirasa paling sesuai untuk mendapatkan jawaban atas permasalahan yang telah dirumuskan sebelumnya yaitu melihat dan memahami Gerakan Warga Berdaya sebagai gerakan masyarakat urban dalam aspek bentuk, pola, dan jaringan aktivisme mereka. Selain itu pendekatan ini juga dipilih untuk dapat lebih memahami narasi apa yang sedang dibongkar oleh Warga Berdaya melalui serangkaian aksinya. Menurut banyak literatur, pemahaman kasus pada pendekatan ini lebih banyak cenderung pada lokasi atau setting penelitian. Asumsi dasar dari pendekatan studi kasus ini adalah sebuah fenomena atau kasus yang berkembang di masyarakat tidaklah datang mendadak dan tiba-tiba. Sederhananya, setiap kasus mempunyai akar yang dapat diidentifikasi dan memerlukan proses melibatkan banyak anggota masyarakat dalam bentuk respon dan stimulan (Usman, 2005).

Sebuah kasus juga pasti memiliki konteks, artinya apabila konteks itu diabaikan maka bisa jadi kasus tersebut menjadi tidak menarik untuk dipermasalahkan. Dalam penelitian ini, konteks permasalahan terletak pada hilangnya ruang publik sebagai arena yang cukup signifikan dalam proses interaksi masyarakat di tengah modernitas perkotaan. Proses interaksi melalui ruang publik merupakan hal yang penting di Yogyakarta, mengingat dari sanalah karakterisrik identitas kota dan kondisi sosial psikologis masyarakat terbangun. Dalam kesenjangan ini, Gerakan Warga Berdaya mengambil peran melalui beragam aktivismenya sebagai upaya menggugat ruang publik di Yogyakarta. Hal tersebut dapat dipahami bahwa kelebihan dari pendekatan studi kasus adalah mampu mengungkapkan hal-hal yang unik secara lebih terperinci. Mengingat fokus perhatian dari penelitian ini adalah fenomena yang terjadi pada sebuah lokasi atau setting tertentu, maka hakekat dan latar belakang terjadinya fenomenan dapat diungkap secara lebih jelas dan mendalam.
Terdapat beberapa strategi dalam metode studi kasus yakni eksploratif, eksplanatoris dan deskriptif. Penggunaan ketiga strategi tersebut tidak bersifat tajam ataupun tegas. Hal tersebut mengingat banyaknya wilayah yang berpotensi untuk saling tumpang tindih. Untuk menentukan strategi yang benar-benar tepat maka yang perlu diperhatikan yaitu terkait dengan tipe pertanyaan penelitian yang diajukan, luas kontrol yang dimiliki peneliti atas peristiwa perilaku yang akan diteliti, dan fokusnya terhadap peristiwa kontemporer sebagai kebalikan dari peristiwa historis (Yin, 1996). Dalam penelitian ini, pertanyaan yang diajukan memiliki tipe "bagaimana". Dari tipe tersebut dapat dilacak bahwa penelitian akan lebih bersifat eksplanatoris, hal tersebut berkaitan dengan operasional yang menuntut pelacakan waktu tersendiri, bukan sekedar frekuensi atau kemunculan. Pada pendekatan studi kasus, kontrol terhadap peristiwa hampir tidak ada. Hal tersebut disebabkan karena fokus studi kasus lebih dikehendaki untuk melacak peristiwa kontemporer.

\section{BEBERAPA KAJIAN TEORITIK MENGENAI RUANG}

\section{Teori Ruang: The Reproduction of Space}

Definisi ruang memiliki banyak makna bila dilihat dari berbagai sudut pandang. Jika dilihat dalam aspek geografis, ruang merupakan sebuah tempat manusia berada dan beraktivitas. Sementara dalam aspek sosiologis, ruang memungkinkan individu untuk berinteraksi dan menciptakan nilai serta norma. Definisi ruang bagi para filsuf memiliki pemahaman yang berbeda-beda. Bagi Plato, ruang adalah sesuatu yang dapat terlihat dan teraba karena memiliki karakter yang jelas dan berbeda dengan semua unsur lainnya. Sementara itu dalam magnum opusnya "Production of Space" (1974), Henri Lefebvre mengatakan bahwa ruang dirproduksi secara sosial terhadap ruang yang terbentuk oleh pikiran kita. Istilah produksi yang digunakan oleh Lefebvre berhubungan dengan produksi sosial yang mencakup aspek keruangan. Makna produksi di sini bukanlah mengenai 
produksi dari sebuah barang atau jasa, namun merupakan sebuah proses dari banyaknya keragaman karya yang dibentuk.

Lefebvre sendiri merupakan filsuf NeoMarxis, yang meskipun pada masanya ia tidak seterkenal Althousser, Gramsci atau Habermas, namun ia memberikan sumbangsih terhadap konsepsi ruang dalam perspektif Marxian. Ruang tidak lagi dipandang sebagai kapital, namun relasi produksi tidak akan bisa berjalan tanpa adanya ruang, selain itu ruang adalah entitas dinamis yang terus diproduksi. Titik tolak yang penting dari "The Production of Space" adalah kontribusi atas satu aspek yang tidak terbayangkan sebelumnya oleh kaum Marxis, Strukturalis dan bahkan oleh Marx sendiri. Yaitu peran ruang, peran spasialisasi dalam kehidupan manusia dan bagaimana perebutan wacana yang terjadi di dalamnya. Jika Marx berbicara mengenai relasi produksi dan akumulasi kapital, maka itu semua tidak dapat berlangsung tanpa adanya ruang. Relasi produksi itu sendiri juga menciptakan ruang yang khusus diperuntukkan baginya. Kapitalisme bahkan lebih jauh lagi, menjadikan ruang sebagai sarana dari akumulasi kapital. Misalnya tanah dan bangunan sebagai aset.Relasi sosial menciptakan ruang, akan tetapi yang lebih penting bagi Lefebvre adalah melihat bahwa ruang sosial adalah produk sosial. Ruang sosial memiliki logika yang panjang untuk menjelaskan dirinya sendiri. Lefebvre menjelaskan,

"(Social) space is a (social) product ... the space thus produced also serves as a tool of thought and of action; that in addition to being a means of production it is also a means of control, and hence of domination, of power; yet that, as such, it escapes on part from those who would make use of it. The social and political (state) forces which engendered this space now seek, but fail, to master it completely; the very agency that has forced spatial reality towards a sort of uncontrollable autonomy now strives to run it into the ground, then shackle and enslave it." (1991, 26-27)
Secara sosial, ruang menjadi sarana untuk meraih dan menciptakan kontrol. Ruang dikonstruksi sedemikian rupa sebagai sarana pemikiran dan tindakan, yang koheren sifatnya dengan upaya kontrol dan dominasi dalam relasi produksi Marx. Dalam pengertian ini ruang diproduksi sedemikian rupa untuk melanggengkan kekuasaan dan menciptakan dominasi. Itu sebabnya, pada bagian awal dari "The Production of Space," Lefebvre lebih fokus kepada persoalan bagaimana peradaban Barat menciptakan konsep ruang melalui konstruksi dan struktur ilmu pengetahuan. Ia memersoalkan bagaimana relasi sosial juga menciptakan akumulasi pengetahuan yang pada akhirnya berperan dalam konstruksi wacana tentang ruang. Jauh sebelum manusia menyadari bagaimana ruang itu seharusnya diperlakukan (dikapitalisasi, misalnya), wacana tentang ruang telah terbentuk lebih dahulu. Setidaknya wacana ini telah menjadi konsep dasar bagi manusia untuk membuat kategori, memilah, memisahkan dan menyekat ruang-ruang fisik yang ada dalam kesehariannya. Lefebvre mengungkapkan,

"The first implication is that (physical) natural space is disappearing. Granted, natural space was - and it remains - the common point of departure: the origin, and the original model, the social process perhaps even the basis of all 'originality'. Granted too, that natural space has not vanished purely and simply from the scene ... As source and as resource, nature obsesses us, as do childhood and spontaneity, via the filter of memory ... Nature is also becoming lost to thought ... Even the powerful myth of nature is being transformed into a mere fiction, a negative utopia: nature is seen as merely the raw material out of which the productive forces of a variety of social systems have forged their particular spaces. True, nature is resistant, and infinite in its depth, but it has been defeated, and now waits only for its ultimate voidance and destruction." (1991, 30-31). 


\section{Representasi Ruang}

Wacana lain di luar praktik spasial dalam tataran fisik yang disebutkan di atas adalah berbagai wacana yang diperlukan untuk memroduksi atau mengonstruksi ruang. Lefebvre menjelaskan bahwa ruang yang dikonseptualisasi sebagai wacana adalah ruang itu sendiri. Secara terstruktur, ruang dikonseptualisasi menjadi sebuah abstraksi dan ilmu oleh para ilmuwan, seperti arsitek, ahli planologi, insinyur sipil, pemegang kebijakan, pemerintah. Abstraksi secara terus-menerus diwacanakan pada akhirnya menjadikan ruang runtuh ke dalam representasi. Wacana dan konsepsi tentang ruang hanya memungkinkan persoalan ruang dipraktikkan secara verbal dan melalui representasi bahasa dan sistem tanda. Ia mengatakan bahwa ruang ini adalah

“... the dominant space in any society (or mode of production) ... towards a system of verbal (and therefore intellectually worked out) signs." $(1991,39)$.

Ruang Urban merupakan contoh yang paling tepat. Terminologi "Ruang Urban" itu sendiri merupakan produksi dari praktik intelektual melalui sistem tanda yang verbal, dan terartikulasikan dalam ruang ilmu pengetahuan. Terminologi Ruang Urban hadir sebagai istilah yang merepresentasikan ruang hidup (Lived Space) manusia kontemporer di perkotaan. Dalam ruang hidup ini, praktik spasial terjadi dan terus-menerus mengapropriasi spasialitas sehari-hari manusia urban. Lebih jauh lagi, spasialitas ini kemudian dipersepsi oleh ilmuwan yang ahli di bidang ruang (sebagai Perceived Space) dan kemudian secara verbal dipersoalkan dalam berbagai diskusi akademik. Dalam diskusi akademik tersebut, ruang yang dibicarakan sama sekali tidak hadir secara fisik. Namun hasil dialog akademis tersebut menghasilkan ruang baru (berupa Conceived Space), yaitu wacana ilmiah tentang ruang (dari ruang fisik di kota) yang dibicarakan. Dari situlah konsepsi terhadap ruang tertentu hadir dan melembaga sebagai wacana. Ruang yang kemudian diproduksinya secara fisik tidak akan mungkin mewujud tanpa adanya gagasan dan sketsa tersebut. Hal inilah yang Lefebvre maksud sebagai relasi antara Perceived, Conceived dan Lived Space. Ia menggambarkan relasi tersebut,

"Relations between the three moments of the perceived, the conceived and the lived are simple or stable, nor are they 'positive' in the sense in which this term might be opposed to 'negative', to the indecipherable, the unsaid, the prohibited, or the uncounscious. ... The fact is, however, that these relationships have always had to be given utterance, which is not the same thing as being known - even 'uncosciously'." (1991, 46).

\section{Urban Movements}

Berangkat dari data empiris tersebut, penulis berupaya membahas fenomena sosial ini dengan menggunakan teori gerakan masyarakat urban (urban movements). Berbicara mengenai gerakan, selama ini kita lebih banyak mengenal teori gerakan sosial dengan dua kategorisasi di dalamnya, yakni gerakan sosial lama (old social movements) dan gerakan sosial baru (new social movements). Gerakan sosial lama berkonsentrasi terhadap dua tema besar, yakni perbaikan ekonomi melalui perjuangan kelas (the theme of class struggle) dan perjuangan ideologi politik (the theme of political ideology). Sementara itu, gerakan sosial baru merupakan respon atas masyarakat pos-industri, berkonsentrasi terhadap isu-isu kontemporer seperti politik identitas dan kualitas hidup meliputi; etnisitas, ras, perdamaian, isu perempuan, lingkungan sampai orientasi seksual. Aktor penggeraknya sendiri, tidak lagi terkotak pada kelas pekerja dan petani sebagaimana aktor-aktor dominan dalam gerakan sosial lama, melainkan melibatkan kelas menengah seperti mahasiswa, kaum intelektual, anak muda dll (Barker, 2000: 125).

Dalam bingkai gerakan (movements), dapat dikatakan bahwa gerakan masyarakat urban merupakan salah satu bentuk dari 
gerakan sosial baru. Gerakan masyarakat urban mengangkat permasalahan perkotaan sebagai isu utama dengan melibatkan seluruh elemen kelas sosial dalam masyarakat. Dalam esainya bertajuk Urban Movements, Hans Pruijt (2010) menjelaskan,

"urban movements are social movements through which citizens attempt to achieve some control over their urban environment. The urban environment comprises the built environment, the social, fabric of the city, and the local political process".

Sementara itu, terdapat alternatif terminologi lain untuk menyebut gerakan ini sebagai urban social movements. Namun demikian, Pickvance (2003) menyarankan terminologi urban movements (gerakan masyarakat urban), karena lebih tepat, jujur dan sejalan dengan environmental movements (gerakan lingkungan) daripada environmental social movements (gerakan sosial lingkungan).

Terminologi urban movements sendiri selama ini lebih dekat dengan studi geografi kota (urban geography). Namun demikian, membahas fenomena kota tidak akan lepas dengan masyarakat dan struktur sosial yang melingkupinya. Sosiologi mengambil peran dalam hal ini melalui sub-studinya yaitu sosiologi perkotaan. Studi sosiologis mengenai gerakan masyarakat urban muncul pasca peristiwa 10 Mei 1968 di Perancis. Sebelumnya, studi sosiologi perkotaan hanya berfokus pada isu komunitas dan integrasi sosial sebagai tujuan dan dampak dari pembangunan (development) politik ekonomi masyarakat dan konflik kepentingan. Salah satu tokoh sosiologi perkotaan yang berusaha mengisi kesenjangan antara hubungan masyarakat dan kota adalah Manuel Castells melalui bukunya "The Urban Question" (1972). Ia menyajikan model dinamika sistem perkotaan dengan satu mekanisme tunggal untuk mencapai perubahan struktural. Castells menyebut mekanisme ini sebagai gerakan masyarakat urban. Lebih lanjut menurut Castells dalam Pruijt (2010), gerakan masyarakat urban berusaha menunjukkan permasalahan yang dialami oleh warga kota melalui aksi kolektif. Masyarakat urban menurutnya menghadapi permasalahan "konsumsi kolektif" (collective consumption) seperti: kurangnya pemukiman, harga sewa rumah yang terlalu mahal, kesehatan dan pendidikan.

Studi mengenai gerakan masyarakat urban bergerak melebihi dokumentasi dan penjelasan mengenai kemenangan atau kekalahan individual dalam konteks konflik serta gerakan masyarakat. Akan tetapi, gerakan masyarakat urban telah berkontribusi untuk membuat perubahan sosial. Manuel Castells (1972) mengelaborasi ide bahwa gerakan masyarakat urban memiliki fungsi laten dalam konteks perjuangan kelas. Gerakan masyarakat urban dapat berjalan signifikan untuk perubahan sosial apabila gerakan tersebut berelasi dengan organisasi yang melibatkan pemahaman tentang kelas dalam model produksi. Lebih jauh, Castells (1983) menjabarkan bahwa fokus dalam gerakan masyarakat urban sudah melebihi transformasi produksi, komunikasi, dan kontra pemerintah (negara); namun ini merupakan upaya perubahan sosial ketika gerakan masyarakat urban mampu memproduksi pertentangan terhadap struktur dominan, atau dengan kata lain merubah pemaknaan terhadap struktur sosial kota (urban meaning) dan menghasilkan kondisi reaktif utopis (reactive utopias).

Menurut Castells gerakan ini dapat mencapai tujuan utama mereka-yakni perubahan sosial-dengan tiga prasyarat. Pertama, merealisasikan kebutuhan kolektif (sandang, pangan, dan papan), yakni memperjuangkan kota menggunakan "nilainilai sosial" melawan komodifikasi dan gentrifikasi. Kedua, menetapkan dan mengukuhkan identitas kulturalnya, serta menciptakan pola komunikasi yang egaliter daripada satu arus (programmed one-way information flows). Terakhir atau ketiga, mampu memenuhi kebutuhannya sendiri. Gerakan masyarakat urban menjadi penting karena dapat melibatkan setiap elemen dalam masyarakat, meleburkan batas/sekat 
sosial melalui mobilisasi lintas kelas. Hal ini membentuk pola kerjasama horizontal dari berbagai elemen, seperti mahasiswa sebagai kelas menengah yang membantu kaum miskin kota (misalnya pekerja imigran). Dalam konteks harapan warga, penulis menginterpretasi bahwa masalah konsumsi kolektif, tidak hanya sekedar kebutuhan fisik. Akan tetapi, berkembang ke perencanaan kota dengan melibatkan struktur yang terlibat di dalamnya. Pada negara dunia ketiga, hal ini menjadi problematis mengingat maraknya pemukiman kumuh, pembangunan yang tidak terencana, ketidaksesuaian pembangunan dengan perizinan, masalah etnisitas dll.

\section{GAGASAN KRITIS: Bentuk, Pola dan Jaringan Aktivisme 'Warga Berdaya'}

Pada intinya penelitian ini terfokus dalam beberapa hal yakni; perubahan fisik dan sosial di Yogyakarta dengan mengambil rentang waktu tahun 2012-2015, respon masyarakat terhadap perubahan fisik dan sosial, kemunculan berbagai komunitas yang peduli terhadap tata ruang kota, dan kemunculan serta aktivisme Warga Berdaya sebagai gerakan masyarakat urban. Untuk memudahkan penggambaran atau framing, maka penulis membuat gambar alur sebagai berikut ini:

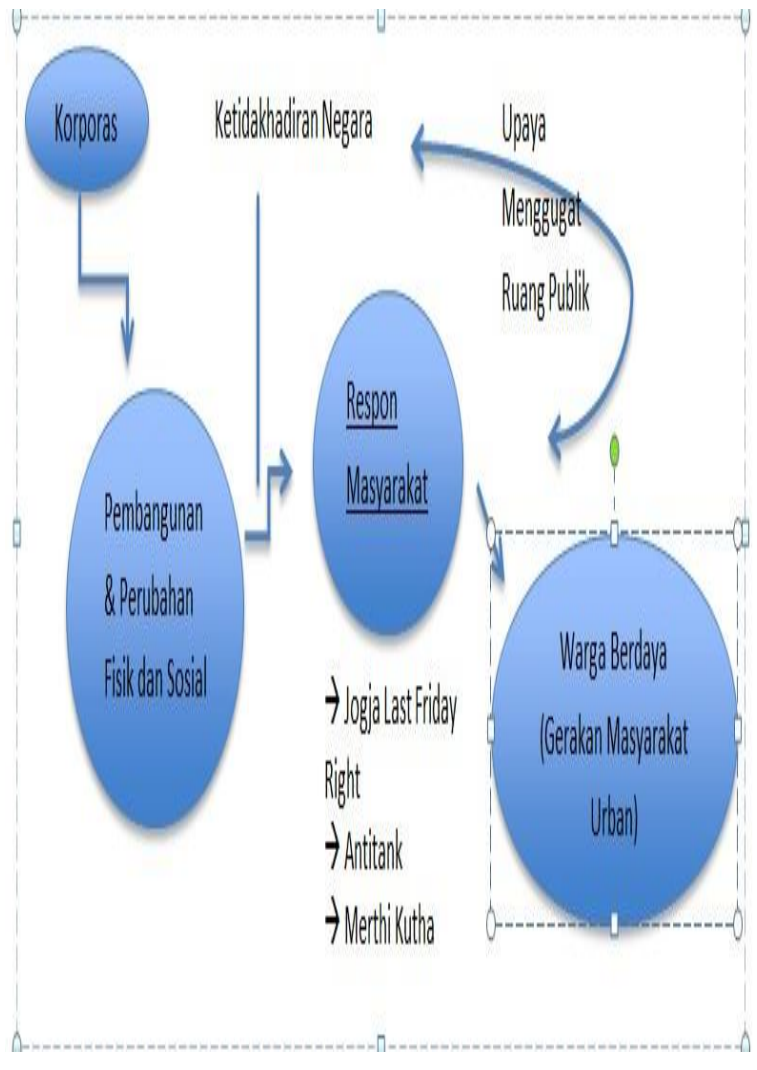

Gambar. 1. Alur Framing Gerakan Warga Berdaya

Kerangka berpikir secara kritis ini diawali dengan konstruksi identitas dan citra Yogyakarta sebagai Kota Pendidikan, Kota Budaya dan wisata yang hingga kini masih memegang teguh nilai-nilai luhur yang diwariskan. Dalam hal ini penulis akan mendedah keberadaan ruang publik di Yogyakarta dan bagaimana kondisinya, apakah representatif dan layak atau justru jauh dari kata memadai. Setelah itu, penulis akan berusaha melakukan pemetaan mengenai periodisasi waktu, kapan dan mometum apa yang menyebabkan Yogyakarta berkembang secara pesat menjadi sebuah kota yang modern dan kosmopolitan. Penulis juga akan melihat bagaimana respon masyarakat dari beragam aktivisme yang dilakukan oleh komunitas-komunitas untuk menggugat ruang-ruang publik yang sebelumnya dapat diakses dengan mudah. Eskalasi aksi/aktivisme akan dijelaskan secara terperinci sampai terbentuknya Gerakan Warga Berdaya. Di sini penulis akan melihat dan memahami bagaimana aktivisme dan transformasi Gerakan Warga Berdaya. 
Selain itu, penting juga untuk melihat bagaimana respon ruang kota terhadap gerakan ini. Sebagai gerakan yang awalnya sporadis, gerakan ini tengah mengemuka dan dipandang sebagai kekuatan sipil yang berpengaruh. Menjadi poin penting bagi penulis untuk melihat bagaimana respon ruang dan kota itu sendiri terhadap gerakan.

\section{SEJARAH MEMPERJUANGKAN RUANG PUBLIK DI KOTA YOGYAKARTA}

Keberadaan perguruan tinggi, komunitas, gerakan mahasiswa, lembaga swadaya masyarakat, kantung-kantung kesenian telah membuat akulturasi dan diseminasi informasi serta pengetahuan kian terbuka dan cair di Yogyakarta. Pertemuan seniman, akademisi, aktivis dalam berbagai kesempatan memunculkan inisiatif-inisiatif yang menarik dalam merespon fenomena sosial-budaya yang berlangsung. Pertemuan ini tidak hanya berlangsung dalam diskusidiskusi formal, namun juga pameran seni, pertunjukan teater sampai diskusi sastra yang marak berlangsung tidak hanya di kampus, juga di komunitas-komunitas kreatif Yogyakarta.

Isu seputar kekerasan, buruh, HAM, dan kebebasan pers menjadi topik yang seringkali diperbincangkan dalam berbagai kesempatan diskusi pada rentang tahun 1980 hingga awal 1990. Selain itu, juga tumbuh subur gerakan, lembaga sampai aksi komunitas yang membahas isu-isu sektoral dalam cakupan yang lebih sempit. Mengambil contoh kehadiran Yayasan Annisa Swasti (Yasanti) yang berdiri di Yogyakarta pada 1982 dengan berfokus pada pembinaan buruh dan petani perempuan.

Pasca reformasi, beberapa gerakan diantaranya melembagakan diri menjadi lembaga swadaya masyarakat (LSM) dan terkonsentrasi dalam isu masing-masing. Di luar lembaga-lembaga formal yang telah terbentuk, muncul pula inisiatif-inisiatif warga yang tidak terbatas pada profesi, latar belakang, suku, atau golongan. Inisiatif warga yang muncul cenderung bersifat interdisipliner-beranggotakan seniman, budayawan, sastrawan, akademisi, dan aktivis yang memiliki minat atau ketertarikan pada isu-isu tertentu.

Berkenaan dengan ruang publik di Yogyakarta, pada tahun 2003 muncul sebuah inisiatif warga bernama Komunitas Peduli Ruang Publik Kota (KERUPUK). Komunitas ini diinisiasi oleh Anggi Minarni (Direktur Karta Pustaka Yogyakarta) dengan mengajak rekan-rekan seniman serta akademisi untuk duduk bersama membahas perubahan fisik dan sosial yang terjadi di Yogyakarta. Cikal bakal aksi Kerupuk adalah merespon proyek renovasi Mataram Boulevard yang berada di Jalan Suroto, Kotabaru. Mataramboulevard yang semula dilingkupi oleh tempat duduk dan pepohonan akan ditutup oleh pot-pot besar oleh Dinas Kebersihan, Keindahan dan Pemakaman (DKKP) Kota Yogyakarta dengan alasan reboisasi. Proyek yang saat itu diperkirakan akan berlangsung pada bulan Februari 2003 ini menuai protes karena kejanggalan-kejanggalan yang ditemukan.

Salah satu momentum penting yang menandai kemunculan kembali gerakan sosial yang menggiatkan isu tentang ruang publik terjadi setelah suksesi walikota Yogyakarta pada tahun 2012. Yakni pergantian kepemimpinan dari Hery Zudianto ke Haryadi Suyuti. Warga mulai menyoroti kinerja Haryadi semenjak ia menghapuskan kebijakan "Sego SegaweSepeda Kanggo Sekolah Lan Nyambut Gawe" melalui surat keputusan SE No. 645/57/SE/2012 pada tanggal 7 September 2012. Sebelumnya, pada periode kepemimpinan Hery Zudianto, sang walikota mewajibkan setiap Pegawai Negeri Sipil (PNS) pada hari Jumat mengendarai sepeda di area Balaikota. Begitu pula dengan PNS di instansi/lembaga lain yang berada di luar area Balaikota. Kebijakan ini telah berlangsung semenjak tahun 20012006 dan 2006-2012, atau selama dua periode pemerintahan. 
Beberapa kelompok menyadari hal tersebut dan mengindikasikan terjadinya inkonsistensi komitmen yang dilakukan oleh Haryadi Suyuti. Kelompok-kelompok tersebut adalah kelompok pegiat sepeda yang aktif dalam kegiatan Jogja Last Friday Ride, serta kelompok masyarakat yang tergabung dalam komunitas mural (Street Art Community). Mereka beranggapan bahwa permasalahan ini dapat menular ke persoalan publik yang lain, misalnya terkait isu trotoar, difabel dll. Oleh karena itu, dua komunitas tersebut berusaha menyelesaikan masalah dengan turun ke jalan. Sebagai wujud kritik, para pegiat mural dan sepeda ini secara swadaya mengecat kembali marka jalan sepeda dan lalu lintas di sejumlah jalan arteri. Mereka juga mempertanyakan keputusan walikota yang dinilai sepihak.

Pada awal 2013, mulai muncul diskusi intensif yang mengerucut membahas isu-isu perkotaan dengan diinisiasi oleh sejumlah aktivis atau tokoh yang merepresentasikan lembaga-lembaga tertentu di Yogyakarta. Kebanyakan, mereka bersal dari disiplin yang berbeda-yakni DigieSigit (pegiat street art), Yoan Vallone (Jogja Last Friday Ride), Sumbo Tinarbuko (pegiat komunitas Reresik Sampah Visual) dan Wahana Lingkungan Hidup (WALHI). Dalam diskusi lanjutan, tergabung pula aktivis dan pegiat lingkungan dari komunitas lain. Isu-isu ruang publik perkotaan yang dibahas meliputi; fasilitas untuk difabel dan pejalan kaki, PKL, sampai persoalan sampah visual.

Akhirnya pada tanggal 10 Februari 2013 diadakan kegiatan "Merthi Kutha"- atau Merawat Kota. Konsep dan analogi "Merthi Kutha" ini diadopsi dari tradisi merawat desa yang sering dilakukan oleh warga di pedesaan, atau yang dikenal dengan istilah "Merthi Ndeso". Aksi yang dilakukan dalam "Merthi Kutha" ini terbagi menjadi tiga yaitu; (1)Perbaikan jalur sepeda di sepanjang Jalan Jenderal Soedirman; (2) Pengecatan jalur khusus difabel di sepanjang Jalan Mangkubumi; (3) Pembersihan sampah visual sepanjang Jalan Sudirman-Mangkubumi-Jembatan Kewek. (Sampah visual yang dimaksud oleh gerakan ialah berbagai macam reklame, brosur, baliho, pamphlet dll yang dipasang ditempat yang tidak semestinya seperti; di pohon, halte, lampu lalu lintas dan fasilitas umum lainnya yang merusak keindahan kota).

Adapun kelompok masyarakat yang terlibat dalam aksi monumental ini antara lain; Komunitas Pemerhati Cagar Budaya, Komunitas Pejalan Kaki, Komunitas Difabel, Komunitas Reresik Sampah Visual dan puluhan masyarakat kota yang turun langsung saat aksi dilakukan. Berbagai komunitas yang berpartisipasi ini juga mencatat berbagai permasalahan yang mereka temui dalam perjalanan "Merthi Kutha". Fungsinya adalah sebagai penanda pekerjaan rumah yang perlu sama-sama diselesaikan bersama antara warga dan pemerintah.

\section{MEMPERSOALKAN "RUANG PUBLIK": PERLUASAN KOTA DAN KOMERSIALISASI RUANG}

Dalam aspek lain, Kabupaten Sleman yang didominasi perguruan tinggi membuka peluang bagi para pemilik modal untuk membangun sejumlah prasarana bagi kebutuhan mahasiswa. Kost eksklusif adalah salah satu hunian yang kini jamak ditemukan terutama di daerah Pogung, Demangan dan baru-baru ini Seturan. Kafekafe dengan fasilitas Wi-Fi pun menjamur dalam rangka memenuhi kebutuhan sosial mahasiswa sebagai kelas menengah baru, baik mengerjakan tugas bersama atau sekedar nongkrong. Hal ini terlihat di daerah Demangan, Seturan hingga Babarsari. Atmosfer Yogyakarta sebagai Kota Pendidikan tak berbekas digantikan dengan kafe, restoran cepat saji, sampai tempat hiburan malam. Menjamurnya tempat-tempat ini juga menciptakan gejala konsumerisme dan memisahkan jarak antara mahasiswa dengan lingkungan sosialnya.

Kabupaten Sleman seolah menjadi target sasaran utama bagi pembangunan 
kompleks, apartemen, dan condotel. Keberadaan institusi pendidikan, kemudahan transportasi, akses air, serta cuaca yang lebih nyaman disinyalir menjadi faktor pendorong. Pembangunan gedunggedung pencakar langit ini tak sedikit yang bermasalah. Salah satu yang hingga kini menuai polemik adalah pembangunan Apartment Uttara di Pedukuhan Karangwuni. Selain Uttara, masih berlangsung pula pembangunan Mataram City Apartment and Hotel (Jalan Palagan Tentara Pelajar), Student Castle Apartment (Seturan), Hartono Mall (Ringroad Utara) dll. Sementara itu di Kota Yogyakarta, pembangunan hotel terlihat di berbagai sudut kota. Berangkat dari Jalan Mangkubumi, telah berdiri dua hotel berbintang empat dengan posisi berdekatan. Hotel 101 berada di sebelah utara jalan, sementara itu terdapat Harpeer Hotel di bagian selatan. Wilayah Gowongan-berdasarkan pengamatan penulis-telah dibangun tiga hotel berbintang dalam rentang waktu 20132015, yakni Horison Hotel, Amaris dan Whiz Hotel. Sementara itu, menuju daerah selatan, Awana Town House tengah dibangun di Jalan MT. Haryono. Tak kurang sepanjang tahun 2010 hingga 2014, berdasarkan statistik resmi DIY, terdapat 29 hotel baru dibangun.

\begin{tabular}{|l|l|l|l|l|l|l|}
\hline Tahun & \multicolumn{3}{|c|}{ Bintang } & \multicolumn{3}{c|}{ Non Bintang } \\
\hline & Akomodasi & Kamar & $\begin{array}{c}\text { Tempat } \\
\text { Tidur }\end{array}$ & Akomodasi & Kamar & $\begin{array}{c}\text { Tempat } \\
\text { Tidur }\end{array}$ \\
\hline 2004 & 36 & 3.416 & 5.555 & 1.092 & 11.278 & 17.307 \\
\hline 2005 & 36 & 3.415 & 5.537 & 1.089 & 11.221 & 17.228 \\
\hline 2006 & 37 & 3.458 & 5.640 & 1.046 & 11.307 & 17.459 \\
\hline 2007 & 38 & 3.458 & 5.640 & 1.039 & 11.307 & 17.459 \\
\hline 2008 & 34 & 3.297 & 5.439 & 1.095 & 12.158 & 18.270 \\
\hline 2009 & 34 & 3.373 & 5.633 & 1.092 & 12.091 & 17.735 \\
\hline 2010 & 36 & 3.631 & 5.807 & 1.098 & 12.519 & 18.293 \\
\hline 2011 & 41 & 3.953 & 6.389 & 1.063 & 12.407 & 18.586 \\
\hline 2012 & 54 & 5.150 & 8.171 & 1.100 & 13.309 & 21.720 \\
\hline 2013 & 61 & 5.801 & 9.280 & 1.109 & 13.547 & 21.549 \\
\hline
\end{tabular}

Tabel.1 Jumlah Akomodasi Hote,, Kamar dan Tempat Tidur di DIY 2004-2013/Unit (sumber: BPS)

\begin{tabular}{|c|c|c|c|c|c|c|}
\hline \multirow{2}{*}{$\begin{array}{l}\text { Kabupaten/Kota } \\
\text { Regency/ City }\end{array}$} & \multicolumn{2}{|c|}{$\begin{array}{l}\text { Hotel Bintang } \\
\text { Star Hotels }\end{array}$} & \multicolumn{2}{|c|}{$\begin{array}{l}\text { Non Bintang } \\
\text { Non Star Hotels }\end{array}$} & \multicolumn{2}{|c|}{ Jumlah/ Total } \\
\hline & 2013 & 2014 & 2013 & 2014 & 2013 & 2014 \\
\hline (l) & (2) & (3) & (4) & (5) & (0) & (7) \\
\hline Kullonpogogo & . & . & 26 & 27 & 26 & 27 \\
\hline Bantul & 1 & 1 & 278 & 248 & 279 & 249 \\
\hline Gunungkidul & 1 & 1 & 61 & 70 & 62 & 71 \\
\hline Sleman & 21 & 26 & 379 & 366 & 400 & 392 \\
\hline Yogyakarta & 39 & 43 & 362 & 356 & 401 & 399 \\
\hline Jumlah/ Total & 62 & 71 & 1.106 & 1.067 & 1.168 & 1.138 \\
\hline
\end{tabular}

Tabel.2 Jumlah Hotel di DIY tahun 20132014 (Sumber: Badan Pusat Statistik DIY, 2014)

Akselerasi pembangunan fisik ini menuai polemik di Yogyakarta. Polemik yang terjadi bukan tanpa sebab. Mayoritas warga setempat merasa 'kecolongan' karena tidak dilibatkan dalam proses pra-konstruksi. Warga juga merasa khawatir karena pembangunan yang dilakukan di tengah pemukiman berisiko terhadap keamanan dan keselamatan. Peran pemerintah di sini mulai dipertanyakan, terutama mengenai kajian-kajian pra konstruksi seperti Analisis Mengenai Dampak Lingkungan (AMDAL) dan izin mendirikan bangunan (IMB) yang begitu mudah diloloskan.

Pembangunan apartemen yang berada di tengah pemukiman, otomatis akan menutup akses jalan dan lalu lintas warga. Ketika proses konstruksi dimulai, keselamatan warga sekitar menjadi taruhannya. Bukan hal yang tidak mungkin bahwa material bangunan dapat jatuh sewaktu-waktu. Warga memahami bahwa proses pembangunan yang masif ini akan berimplikasi negatif bagi mereka sebagai warga Yogyakarta asli. Penulis mengambil contoh keberadaan Fave Hotel Yogyakarta di Jalan Kusumanegara. Warga kampung Miliran telah melakukan aksi protes pada manajemen hotel karena keringnya air di sumur mereka. Warga menganggap pihak hotel telah menyedot air tanah warga untuk kepentingannya, meskipun pihak hotel berdalih telah menggunakan air sumber PDAM. Warga yang telah puluhan tahun 
hidup di kampung Miliran menyatakan bahwa air tanah mereka tidak pernah surut selama ini, namun setelah Fave Hotel dibangun kemudian sumur warga menjadi kering.

Selain dampak fisik yang dikhawatirkan, warga juga mulai mempertanyakan road map perencanaan pembangunan di Yogyakarta, terlebih melihat pembangunan hotel dan apartemen yang kian liar. Warga menilai semangat "Memayu Hayuning Bawana" bertentangan dengan perubahan fisik yang kini terjadi di Yogyakarta. Warga melihat pemerintah yang tidak berpihak pada rakyat, namun lebih condong memerhatikan kepentingan korporasi. Bukan hal yang tidak mungkin apabila Yogyakarta kelak, tak ubahnya seperti Jakarta dengan gedung-gedung pencakar langit dengan lalu lintas semrawut. Keberadaan hotel dan apartemen dipertanyakan oleh warga Yogyakarta;

"Siapa yang membutuhkan itu semua dan segmentasi pasar mana yang dituju?"

Di sisi lain, komersialisasi ruang publik juga terlihat dengan maraknya billboard, baliho, spanduk, reklame di sepanjang ruas jalan di Yogyakarta. Lebih dari itu, pohon, taman, tiang listrik, tiang telepon hingga rambu lalu lintas berubah menjadi panggung iklan, termasuk di dalamnya iklan politik. Billboard dan baliho ini tumpang tindih dan saling berlomba satu sama lain. Hal ini terlihat jelas di ruas Jalan Kaliurang, Jalan Monjali, Jalan Palagan Tentara Pelajar, Jalan Gejayan, Jalan Seturan sampai daerah Babarsari. Satu tahun belakangan, videotron dipasang di beberapa penjuru kota Jogja. Dengan frekuensi yang terus bertambah setiap harinya, medium beriklan ini berubah menjadi sampah visual. Bukan tanpa alasan, namun pemasangan reklame ini tidak mengindahkan estetika kota dan terkadang mengganggu pengguna jalan dalam mencari lokasi.

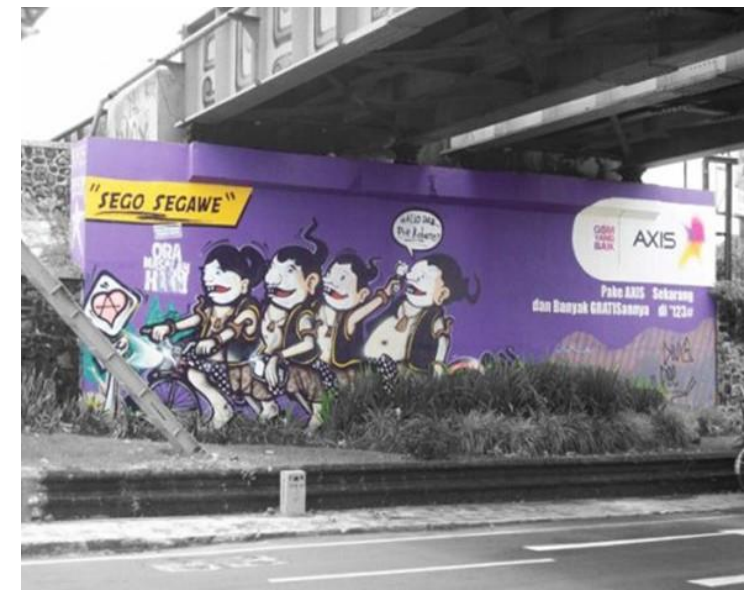

Gambar. 2 Mural di Jembatan Kleringan, Kotabaru (Dokumentasi peneliti, 2014)

Persoalan sampah visual di ruang publik ini memancing emosi warga Yogyakarta ketika salah satu bangunan bersejarah kota, yakni Jembatan Kewek atau Jembatan Kleringan dikooptasi sebagai media beriklan oleh salah satu penyedia jasa telekomunikasi. Jembatan ini dapat dikategorikan sebagai cagar budaya berdasarkan peristiwa Agresi Militer Belanda II tahun 1946. Jembatan Kleringan termasuk dalam potensi heritage di Kota Yogyakarta tahun 2011 yang diterbitkan oleh Dinas Pariwisata dan Kebudayaan Kota Yogyakarta. Sementara itu, berdasarkan Perda Kota Yogyakarta No. 8 Tahun 1998 tidak ada jenis reklame berbentuk mural. Sehingga dalam hal ini, warga merasa pemerintah mulai kehilangan otoritasnya, tunduk terhadap kepentingan sekelompok elit dan mengabaikan azas-azas tata ruang kota.

Berdasarkan penjabaran dan contoh kasus di atas, kita dapat mendeskripsikan ruang publik sebagai ruang yang dimiliki bersama oleh seluruh elemen masyarakat. Ia merupakan salah satu bagian penting dalam kehidupan manusia urban. Ruang publik memungkinkan setiap elemen masyarakat untuk berinteraksi. Keberadaan ruang publik menjadi bagian dalam membentuk karakter masyarakat sekaligus menjadi cerminan budaya dari suatu wilayah. Karakteristik ruang publik sebagai arena interaksi warga dan masyarakat sangat penting dalam menjaga dan meningkatkan 
kualitas kawasan perkotaan, termasuk kondisi psikologis masyarakat. Oleh karena itu pengelolaan ruang publik menjadi hal yang mutlak dilakukan oleh para pemangku kebijakan.

Saat ini, integrasi fungsional ruang publik cenderung memudar. Perkembangan dan pembangunan ruang kota membawa dampak besar pada spesialisasi dan privatisasi fungsi ruang. Ruang publik kota pun cenderung menjadi ruang residual yang digunakan untuk parkir kendaraan atau kegiatan pariwisata dan perdagangan. Tak sedikit pula ruang publik kota yang dikomersilkan sehingga semakin memperburuk kondisi sosial dan psikologis masyarakat. Melihat kotanya kini tidak senyaman dahulu, komunitas-komunitas yang berada di Yogyakarta mulai melakukan aksi sporadis untuk membenahi lingkungannya. Dengan mengedepankan kreativitas, berbagai aksi damai turun ke jalan bergulir tiada henti. Anak muda dari beragam komunitas-mengambil contoh Jogja Last Friday Ride-mengecat ulang marka jalan yang pudar. Sementara itu Komunitas Reresik Sampah Visual mencabuti berbagai spanduk, banner dan rontek yang memadati hampir setiap ruang kosong di penjuru kota. Komunitas street art Anti Tank yang digawangi Andrew Lumban Gaol melakukan aksi kritiknya dengan menempel poster dan membuat mural bernada satire bagi pemerintah di dinding bangunan yang tidak terpakai.

Dalam sisi yang lain, warga juga tetap mengupayakan advokasi dan mediasi pada pemerintah guna penataan ulang ruang kota selain aksi turun ke jalan. Kesadaran warga akan ruang publiknya yang kini dihegemoni oleh sekelompok elit, membuat masyarakat bergerak secara swadaya menuntut ruang publiknya. Keberadaan komunitas yang secara kolektif turun ke jalan ini menarik perhatian bagi penulis untuk melihat kecenderungan apa yang sedang terjadi terhadap masyarakat sipil di Yogyakarta.

Momentum ini semakin terlihat ketika pada tanggal 13 Februari 2013 secara serentak sejumlah komunitas

yang mengatasnamakan dirinya sebagai masyarakat peduli tata ruang kota menggelar aksi bertajuk "Merthi Kutha". Merthi Kuta sendiri merupakan akronim dari masyarakat berdaya benahi ruang kota. Sejak Pukul. 07.00, masyarakat Yogyakarta bergerak membenahi ruang kota dengan rute sepanjang Gondolayu-TuguMangkubumi-Jembatan Kleringan. Merthi Kuta bukan hanya simbol ajakan untuk membersihkan diri dan berbenah kota, namun ia adalah rangkaian tindakan langsung kolaborasi masyarakat. Aksi Merthi Kuta sendiri tidak terbatas pada komunitas, informasi gelaran ini dipublikasikan secara luas sehingga dalam aksinya terdapat warga yang secara spontan turun ke jalan. Dalam aksi tersebut, setiap komunitas dan warga berdasarkan keahliannya mencatat isu dan permasalahan apa saja yang perlu dibenahi, serta mendokumentasikan perubahan fisik dan sosial yang terjadi di sepanjang rute tersebut.

Berlandaskan momentum tersebut, selanjutnya masyarakat peduli tata ruang kota secara konsisten mengkritisi perubahan-perubahan yang terjadi di Yogyakarta terutama yang meyangkut kepentingan bersama dan ruang publik. Pada 15 Mei 2014 kembali diselenggarakan Merthi Kuta kedua, meyoroti Bangunan Cagar Budaya (BCB) yang kini telah beralih fungsi menjadi ruang-ruang komersial. Komunitas street art secara kolektif membersihkan BCB dari sampah-sampah visual yang ada dan mengecat ulang dengan cat putih. Gerakan Warga Berdaya sendiri merupakan kelanjutan aksi dari masyarakat peduli tata ruang kota. Gerakan ini terbuka bagi siapa saja yang ingin memberikan konstribusinya terhadap tata ruang kota. Dalam beberapa bulan terakhir, Warga Berdaya menyoroti pembangunan apartemen dan hotel yang semakin liar. Warga Berdaya menghimpun keluhan warga terdampak dari pembangunan tersebut, mengkaji dokumen-dokumen pemberian izin, kemudian secara konsisten menggelar aksi protes dan melakukan mediasi terhadap pihak korporasi maupun pemerintah. Warga Berdaya juga menyoroti 
proses pra konstruksi apartemen dan hotel yang akan dibangun melalui beragam media. Persoalan yang disoroti belakangan adalah mengenai air tanah. Melalui film yang dibuat secara swadaya bertajuk "Belakang Hotel", Warga Berdaya mencoba membangun kesadaran kritis warga Yogyakarta megenai dampak pembangunan yang akan berimbas pada keringnya (asat) air tanah warga (\#JogjaAsat). Film ini telah diputar di berbagai acara di Yogyakarta, baik yang digawangi oleh komunitas maupun mahasiswa.

\section{Kesimpulan}

Berdasarkan pemaparan kompleks dan deskripsi gerakan sebagaimana yang telah dijelaskan di atas, maka penulis beranggapan bahwa Gerakan Warga Berdaya merupakan sebuah contoh gerakan masyarakat urban yang dinamis. Hal ini menjadi penting mengingat konteks Yogyakarta sebagai wilayah yang sarat aspek sosio, kultural dan historis kini berada di tengah gelombang modernisasi. Di sisi lain kita juga dapat melihat bahwa gerakan sipil saat ini (seiring dengan perkembangan teknologi informasi dan komunikasi) telah menjadi kekuatan yang disegani. Dalam kajian ini penulis akan banyak mengangkat aspek mengenai ruang publik dan tata ruang kota, gerakan masyarakat urban, relasi kuasa dan praktik hegemoni yang terjadi di Yogyakarta.

Kemunculan, perkembangan dan transformasi gerakan masyarakat urban bukan hanya merupakan subjek analisis yang menarik, melainkan juga merepresentasikan gerakan masyarakat urban dengan partisipasi aktif dari beragam elemen masyarakat di dalamnya. Gerakan masyarakat urban tidak dapat dilihat secara tunggal sebagai sebuah gerakan yang menghimpun kekuatan sipil dalam konteks kota. Gerakan itu tidak dapat dipisahkan dari ruang yang melingkupinya sebagai konteks, terlebih yang diperjuangkan dalam Gerakan Warga Berdaya merupakan isu-isu ruang publik. Ruang tidak dapat diperlakukan sebagai latar yang statis, namun ruang secara dinamis mempengaruhi gerakan dan sementara itu gerakan juga saling berkesinambungan membentuk persepsi atas ruang kota.

\section{DAFTAR PUSTAKA}

Castells, M. (1977). The Urban Questions: A Marxisrt Approach. London: Edward Arnold

Castells, M. (1983). The City and The Grassroots: A Cross Cultural Theory of Urban Social Movement, Edward Arnold, London.

Creswell, John W. (2009). Research Design Pendekatan Kualitatif, Kuantitatif dan Mixed. Yogyakarta: Pustaka Pelajar.

Elden, Stuart. (2007). There is a Politics of Space because Space is Political: Henri Lefebvre and the Production of Space. Radical Philosophy Review volume 10, number 2 (2007) 101-106.

Lefebvre, Henri. (1991). The Production of Space, Translated by Donald NicholsonSmith, Oxford: Blackwell.

Lefebvre, Henri.(2002). Critique of Everyday Life, Translated by John Moore, London and New York: Verso.

Moleong, Lexy J. (2009). Metodologi Penelitian Kualitatif (Edisi Revisi 26). Bandung: PT Remaja Rosdakarya.

Nasution, S. (2007). Metode Research (Penelitian Ilmiah). Jakarta: Bumi Aksara.

Pickvance, C. (1984) Review of The City and The Grasroots. International Journal of Urban and Regional Research 8.4, 888-591.

Pruijt, Hans. (2010). Urban Movements. Preprint. Published in: Ritzer, George (ed) (2007) Blackwell Encyclopedia of Sociology, Malden: Blackwell, 5115-5119.

Usman, Sunyoto. (2005). RPKPS Pengantar Metode Penelitian Sosial. Yogyakarta: 
Jurusan Sosiologi, Fakultas Ilmu Sosial dan Ilmu Politik UGM. Hal. 21.

Yin, Robert. K. (1996). Studi Kasus Desain dan Metode. Jakarta: Rajawali Press.

Yogyakarta Dalam Angka (2014). Yogyakarta: Biro Pusat Statistik Yogyakarta. 